\title{
Chemical Pesticides and Human Health: The Urgent Need for a New Concept in Agriculture
}

\author{
Polyxeni Nicolopoulou-Stamati ${ }^{\star *}$, Sotirios Maipas ${ }^{1}$, Chrysanthi Kotampasi', \\ Panagiotis Stamatis ${ }^{1}$ and Luc Hens ${ }^{2}$ \\ ${ }^{1}$ Department of Pathology, School of Medicine, National and Kapodistrian University of Athens, Athens, Greece, ${ }^{2}$ Vlaamse \\ Instelling voor Technologisch Onderzoek (VITO), Mol, Belgium
}

The industrialization of the agricultural sector has increased the chemical burden on natural ecosystems. Pesticides are agrochemicals used in agricultural lands, public health programs, and urban green areas in order to protect plants and humans from various diseases. However, due to their known ability to cause a large number of negative health and environmental effects, their side effects can be an important environmental health risk factor. The urgent need for a more sustainable and ecological approach has produced many innovative ideas, among them agriculture reforms and food production implementing sustainable practice evolving to food sovereignty. It is more obvious than

OPEN ACCESS

Edited by: Robin Mesnage,

King's College London, UK

Reviewed by:

M. Jahangir Alam,

University of Houston College of

Pharmacy, USA

Angelika Hilbeck,

ETH Zurich, Switzerland

*Correspondence:

Polyxeni Nicolopoulou-Stamati aspis@ath.forthnet.gr

Specialty section: This article was submitted to Environmental Health, a section of the journal Frontiers in Public Health

Received: 27 January 2016 Accepted: 04 July 2016

Published: 18 July 2016

Citation:

Nicolopoulou-Stamati P, Maipas S, Kotampasi $C$, Stamatis $P$ and Hens $L$

(2016) Chemical Pesticides and Human Health: The Urgent Need for

a New Concept in Agriculture.

Front. Public Health 4:148.

doi: 10.3389/fpubh.2016.00148 ever that the society needs the implementation of a new agricultural concept regarding food production, which is safer for man and the environment, and to this end, steps such as the declaration of Nyéléni have been taken.

Keywords: pesticides, agrochemicals, environmental health, endocrine disruptors, food sovereignty

\section{INTRODUCTION}

Pesticides are substances or mixtures of substances that are mainly used in agriculture or in public health protection programs in order to protect plants from pests, weeds or diseases, and humans from vector-borne diseases, such as malaria, dengue fever, and schistosomiasis. Insecticides, fungicides, herbicides, rodenticides, and plant growth regulators are typical examples (1-3). These products are also used for other purposes, such as the improvement and maintenance of non-agricultural areas like public urban green areas and sport fields $(4,5)$. Furthermore, there are other less known applications of these chemical substances, such as in pet shampoos (4), building materials, and boat bottoms in order to eliminate or prevent the presence of unwanted species (6).

Many of the pesticides have been associated with health and environmental issues (1, 2, 7-12), and the agricultural use of certain pesticides has been abandoned (2). Exposure to pesticides can be through contact with the skin, ingestion, or inhalation. The type of pesticide, the duration and route of exposure, and the individual health status (e.g., nutritional deficiencies and healthy/damaged skin) are determining factors in the possible health outcome. Within a human or animal body, pesticides may be metabolized, excreted, stored, or bioaccumulated in body fat $(1,2,13)$. The numerous negative health effects that have been associated with chemical pesticides include, among other effects, dermatological, gastrointestinal, neurological, carcinogenic, respiratory, reproductive, and endocrine effects $(1,2,8,10,14-30)$. Furthermore, high occupational, accidental, or intentional exposure to pesticides can result in hospitalization and death $(1,31)$.

Residues of pesticides can be found in a great variety of everyday foods and beverages, including for instance cooked meals, water, wine, fruit juices, refreshments, and animal feeds (32-39). Furthermore, it should be noted that washing and peeling cannot completely remove the residues 
(40). In the majority of cases, the concentrations do not exceed the legislatively determined safe levels $(36,39,41,42)$. However, these "safe limits" may underestimate the real health risk as in the case of simultaneous exposure to two or more chemical substances, which occurs in real-life conditions and may have synergistic effects $(1,43)$. Pesticides residues have also been detected in human breast milk samples, and there are concerns about prenatal exposure and health effects in children (13, 44-46).

This current review aims at highlighting the urgent need for a new concept in agriculture involving a drastic reduction in the use of chemical pesticides. Given the fact that the health effects have been extensively discussed in the current literature, this paper focuses on the major chronic health effects and recent findings regarding health effects that have been associated with exposure to common classes of chemical pesticides, i.e., organochlorines, organophosphates, carbamates, pyrethroids, triazines, and neonicotinoids. More emphasis is given to the widely used herbicide "glyphosate," which is an organophosphate pesticide very closely related to current agriculture (47). The important health effects, as discussed below, reveal the urgent need for implementing alternative solutions.

\section{ORGANOCHLORINE PESTICIDES}

The most widely known organochlorine pesticide is dichlorodiphenyltrichloroethane, i.e., the insecticide DDT, the uncontrolled use of which raised many environmental and human health issues $(2,48,49)$. Dieldrin, endosulfan, heptachlor, dicofol, and methoxychlor are some other organochlorines used as pesticides.

There are a few countries that still use DDT or plan to reintroduce it for public health purposes $(13,48,49)$. Furthermore, DDT is also used as a solution in certain solvents (2). It is a ubiquitous chemical substance, and it is believed that every living organism on Earth has a DDT body burden, mainly stored in the fat $(48,50)$. There is also evidence that DDT and its metabolite p,p-dichlorodiphenyldichloroethylene (DDE) may have endocrine-disrupting potential and carcinogenic action (48). In utero exposure to both DDT and DDE has been associated with neurodevelopmental effects in children (51). Moreover, a recent study related DDE to hepatic lipid dysfunction in rats (50).

The general class of organochlorine pesticides has been associated with health effects, such as endocrine disorders $(10,52)$, effects on embryonic development (53), lipid metabolism (54), and hematological and hepatic alterations (55). Their carcinogenic potential is questioned, but concerns about possible carcinogenic action should not be underestimated $(38,39,56,57)$.

\section{ORGANOPHOSPHORUS PESTICIDES}

Organophosphates, which were promoted as a more ecological alternative to organochlorines (58), include a great variety of pesticides, the most common of which is glyphosate. This class also includes other known pesticides, such as malathion, parathion, and dimethoate; some are known for their endocrinedisrupting potential $(10,59,60)$. This class of pesticides has been associated with effects on the function of cholinesterase enzymes (58), decrease in insulin secretion, disruption of normal cellular metabolism of proteins, carbohydrates and fats (54), and also with genotoxic effects (61) and effects on mitochondrial function, causing cellular oxidative stress and problems to the nervous and endocrine systems (54).

Population-based studies have revealed possible relations between the exposure to organophosphorus pesticides and serious health effects including cardiovascular diseases (62), negative effects on the male reproductive system (63) and on the nervous system $(58,64-66)$, dementia (67), and also a possible increased risk for non-Hodgkin's lymphoma (68). Furthermore, prenatal exposure to organophosphates has been correlated with decreased gestational duration (69) and neurological problems occurring in children (70).

Regarding glyphosate, the safety of which is the subject of an ongoing scientific controversy $(60,71-76)$, it is the most widely used herbicide in current agriculture $(47,75)$, especially since the introduction of glyphosate-tolerant genetically modified crops, such as certain types of soybean and maize $(60,77-80)$. Its extensive use in genetically modified soybean cultivation has raised concerns about possible synergistic estrogenic effects due to the simultaneous exposure to glyphosate and to the phytoestrogen "genistein," which is a common isoflavone present in soybeans and soybean products $(80,81)$.

Glyphosate can display endocrine-disrupting activity $(80,82)$, affect human erythrocytes in vitro (83), and promote carcinogenicity in mouse skin (84). Furthermore, it is considered to cause extreme disruption in shikimate pathway, which is a pathway found in plants and bacteria as well as in human gut bacteria. This disruption may affect the supply of human organism with essential amino acids (85). Commercial glyphosate formulations are considered to be more toxic than the active substance alone $(80,83,86,87)$. Glyphosate-based herbicides, such as the wellknown "Roundup," can cause DNA damages and act as endocrine disruptors in human cell lines (60) and in rat testicular cells (88), cause damages to cultured human cutaneous cells (89), and promote cell death in the testicular cells of experimental animals $(88,90)$. There is evidence also for their possible ability to affect cytoskeleton and intracellular transport (91).

A recent study examined the possible relation between glyphosate, genetically modified crops, and health deterioration in the USA. Correlation analyses raised concerns about possible connections between glyphosate use and various health effects and diseases, such as hypertension, diabetes, strokes, autism, kidney failure, Parkinson's and Alzheimer's diseases, and cancer (82). Furthermore, there are concerns about the possible ability of glyphosate to cause gluten intolerance, a health problem associated with deficiencies in essential trace metals, reproductive issues, and increased risk to develop non-Hodgkin's lymphoma (92).

\section{CARBAMATE PESTICIDES}

Carbamate pesticides, such as aldicarb, carbofuran, and ziram, are another class of chemical pesticides that have been associated with endocrine-disrupting activity $(10,93)$, possible reproductive disorders $(63,93)$, and effects on cellular metabolic mechanisms and mitochondrial function (54). Moreover, in vitro studies have 
revealed the ability of carbamate pesticides to cause cytotoxic and genotoxic effects in hamster ovarian cells (94) and to induce apoptosis and necrosis in human immune cells (95), natural killer cells $(96,97)$, and also apoptosis in T lymphocytes (98).

Furthermore, it has been confirmed that carbaryl, which belongs to the category of carbamate pesticides, can act as a ligand for the hepatic aryl hydrocarbon receptor, a transcription factor involved in the mechanism of dioxin toxicity (99). There is also evidence for the ability of carbamate pesticides to cause neurobehavioral effects $(65,100)$, increased risk for dementia (67), and non-Hodgkin's lymphoma (101).

\section{OTHER CLASSES OF CHEMICAL PESTICIDES}

Triazines, such as atrazine, simazine, and ametryn, are another class of chemical pesticides that have been related to endocrinedisrupting effects and reproductive toxicity $(10,102,103)$. Moreover, it was found that there is a possible statistical relationship between triazine herbicides and breast cancer incidence (104). Atrazine is the most known of the triazines, and it is a very widely used herbicide that has been associated with oxidative stress (103), cytotoxicity $(105,106)$, and dopaminergic effects $(107,108)$. Furthermore, the exposure of experimental animals to atrazine has been associated with reproductive toxicity (109) and delays in sexual maturation (110).

Synthetic pyrethroids, such as fenvalerate, permethrin, and sumithrin, are considered to be among the safer insecticides currently available for agricultural and public health purposes $(111,112)$. However, there is evidence for their ability to display endocrine-disrupting activity $(10,113-115)$, and to affect reproductive parameters in experimental animals including reproductive behavior $(114,116)$. Furthermore, a recent study related more than one pyrethroid metabolite to DNA damages in human sperm, raising concerns about possible negative effects on human reproductive health (117). It should also be mentioned that there are also concerns about their possible ability to display developmental neurotoxicity $(25,118,119)$.

Neonicotinoid pesticides, such as imidacloprid, thiacloprid, and guadipyr, are relatively new and also the most extensively used insecticides (120) that were promoted for their low risk for non-target organisms (121). However, there is plenty of evidence to the contrary $(115,122-125)$; their effect on bees is a common example $(124,125)$. There is also evidence for possible effects on the endocrine and reproductive systems of animals (115, $126,127)$. Moreover, a recent study demonstrated that neonicotinoids are able to increase the expression of the enzyme aromatase, which is engaged in breast cancer and also plays an important role during developmental periods (128).

\section{URGENT NEED TOWARD CLEANER AND SAFER AGRICULTURAL PRACTICES}

Current agricultural practices include the wide production and extensive use of chemicals known for their ability to cause negative health effects in humans and wildlife and to degrade the natural environment. Therefore, an urgent strategic approach is needed for a reduction in the use of agrochemicals and for the implementation of sustainable practices. Furthermore, current agriculture has to implement environmentally friendlier practices that pose fewer public health risks. Reforming agricultural practices aligned to fulfill these criteria is a step toward the sustainability of the agricultural sector in contrast to precision agriculture (129-134).

However, the reduction in the use of agrochemicals by applying them only when and where they are necessary, the spatiotemporal variability of all the soil and crop factors of a given field must be taken into consideration. This variability includes yield, field, soil, and crop variability but also factors, such as wind damage or flooding. Technological systems, such as geographical information systems, global positioning systems, and various sensors, can be useful $(130-132,135)$. These technological systems are developed by precision agriculture which of course we do not endorse, but we consider that selected technological tools can be used to decrease risks for environmental pollution and water pollution and to enhance economic benefits stemming from the reduction in the use of chemical products $(130,132)$.

It should be clear that the reform into an aggregate of machinecentered procedures and losing a human-centered character are not the desired. In contrast, the reduction in the use of pesticides assisted by innovative technological methods we strongly believe that may reduce the use of chemical substances or maybe it can lead to a total abandonment in many cases, such as in the case of urban green areas. The decision of the Italian village of Mals near the Austrian and Swiss borders to ban the use of pesticides and produce pesticide-free foods can be considered as a pioneer example across Europe. In 2014, more than $70 \%$ of the inhabitants of Mals who participated in a referendum voted against the use of pesticides (136). This historical decision apart that is consistent with the food sovereignty concept, which is discussed in the following section, also declares the need for disseminating information for raising awareness of the public in order to develop informed consents.

An innovative idea developed by the international movement "Via Campesina," was the democratic concept of food sovereignty that has accompanied the progress toward sustainability for more than 20 years. It acquired a strong basis in 2007 in the African village Nyéléni in Mali, where representatives from more than eighty countries adopted the "Declaration of Nyéléni." According to its principles, all the people of the world have the right to choose their own national and local policies to eliminate poverty, malnutrition, and hunger, to protect their traditions and also the natural environment (137-141).

The industrialization of agriculture has brought a series of problems including economic, social, and environmental impacts that local populations cannot manage. Furthermore, the overproduction of food, export-oriented monocultures, the demand for cheap labor, and the other characteristics of industrialization have clearly failed to solve the problems of hunger and malnutrition. On the contrary, inequitable food distribution, overexploitation of land and water sources, the overuse of agrochemicals, and the degradation of the natural environment are some of the results of the dominant agricultural model $(138,142-144)$. Food sovereignty 
promotes social, economic, and environmental sustainability, for instance, through the protection of the indigenous population and the production of food for distribution in local markets, and there is an ongoing effort for its recognition as a basic human right (138-140, 142, 145).

The dominant agricultural model has increased the chemical burden on natural environment $(140,142)$. Moreover, international agrochemical companies absorb traditional agricultural companies, leading to an industrialized agriculture model and leaving the local farmers and small producers to face the consequences $(138,143)$. In many cases, these people are obliged to adopt environmentally unfriendly techniques to increase their production in order to survive in the market, causing more environmental degradation (138). However, due to the fact that food sovereignty does not necessarily mean pesticide-free, organic food production, and because it does not determine pesticide use levels, for this reason, international eco-friendly standards should be implemented. People must be free to decide the method of production of their own food, and an important component of this decision concerns agrochemical products. The decision of the people of Mals to reject pesticides can be considered a step in this direction.

\section{DISCUSSION}

The need for protection against pests is a given and has its roots in antiquity, when both organic and chemical substances were applied as pesticides (146). Since then, numerous chemical pesticides have been produced, and now multinational agrochemical companies, which mostly control global food production, apply new chemical substances with pesticide properties and implement biotechnological advances, thus diverging from traditional agricultural methods. Furthermore, current agricultural practices are based on the wide use of chemical pesticides that have been associated with negative impacts on human health, wildlife, and natural environment $(9,11,120,147,148)$.

Current agriculture has to deal with important factors, such as population growth, food security, health risks from chemical pesticides, pesticide resistance, degradation of the natural environment, and climate change (149-155). In recent years, some

\section{REFERENCES}

1. World Health Organization. Public Health Impact of Pesticides Used in Agriculture. England: World Health Organization (1990).

2. Alewu B, Nosiri C. Pesticides and human health. In: Stoytcheva M, editor. Pesticides in the Modern World - Effects of Pesticides Exposure. InTech (2011). p. 231-50. Available from: http://www.intechopen.com/ books/pesticides-in-the-modern-world-effects-of-pesticides-exposure/ pesticide-and-human-health

3. NSW EPA. What Are Pesticides and How Do They Work? (2013). Available from: http://www.epa.nsw.gov.au/pesticides/pestwhatrhow.htm

4. Hoffman RS, Capel PD, Larson SJ. Comparison of pesticides in eight U.S. urban streams. Environ Toxicol Chem (2000) 19:2249-58. doi:10.1002/ etc. 5620190915

5. Canadian Cancer Society. Cosmetic Pesticides. Information Brief. (2013). Available from: https://www.cancer.ca/ /media/cancer.ca/AB/get $\% 20$ involved/take\%20action/CosmeticPesticides-InformationBrief-AB.pdf new concepts regarding agriculture and food production have appeared. A concept as such is climate-smart agriculture that seeks solutions in the new context of climate change $(152,153)$. Another major ongoing controversy exists between the advocates and the opponents of genetically engineered pesticide-resistant plants, regarding not only their safety $(29,156,157)$ but also their impact on pesticide use (158-160).

Furthermore, the real-life chronic exposure to mixture of pesticides with possible additive or synergistic effects requires an in depth research. The underlying scientific uncertainty, the exposure of vulnerable groups and the fact that there are numerous possible mixtures reveal the real complex character of the problem (161-163). The combination of substances with probably carcinogenic or endocrine-disrupting effects may produce unknown adverse health effects. Therefore, the determination of "safe" levels of exposure to single pesticides may underestimate the real health effects, ignoring also the chronic exposure to multiple chemical substances.

Taking into consideration the health and environmental effects of chemical pesticides, it is clear that the need for a new concept in agriculture is urgent. This new concept must be based on a drastic reduction in the application of chemical pesticides, and can result in health, environmental, and economic benefits (164) as it is also envisaged in European Common Agricultural Policy (CAP) (165).

We believe in developing pesticide-free zones by implementing a total ban at local level and in urban green spaces is easily achievable. Furthermore, alternative procedures to the current model of food production should be implemented in new agricultural policies targeting sustainable development and protection of the consumers' health. Despite the difficulties of establishing an innovative concept, the transition to a new cleaner and safer agricultural model is necessary.

\section{AUTHOR CONTRIBUTIONS}

Professor PN-S and Professor LH are the principal authors. Mr. SM contributed with proof reading, literature review, and editing. Mrs. CK and Mr. PS contributed with literature review and editing.

6. Johnston JJ. Introduction to Pesticides and Wildlife. USDA National Wildlife Research Center - Staff Publications. Paper 589 (2001). Available from: http://digitalcommons.unl.edu/icwdm_usdanwrc/589

7. Hayes TB, Case P, Chui S, Chung D, Haeffele C, Haston K, et al. Pesticide mixtures, endocrine disruption, and amphibian declines: are we underestimating the impact? Environ Health Perspect (2006) 114:40-50. doi:10.1289/ ehp. 8051

8. Sanborn M, Kerr KJ, Sanin LH, Cole DC, Bassil KL, Vakil C. Non-cancer health effects of pesticides. Systematic review and implications for family doctors. Can Fam Physician (2007) 53:1712-20.

9. Pimentel D, Burgess M. Environmental and economic costs of the application of pesticides primarily in the United States. In: Pimentel D, Peshin R, editors. Integrated Pest Management. New York, Heidelberg, Dordrecht, London: Springer Science + Business Media Dordrecht (2014). p. 47-71.

10. Mnif W, Hassine AIH, Bouaziz A, Bartegi A, Thomas O, Roig B. Effect of endocrine disruptor pesticides: a review. Int J Environ Res Public Health (2011) 8:2265-2203. doi:10.3390/ijerph8062265 
11. Goulson D. Ecology: pesticides linked to bird declines. Nature (2014) 511:295-6. doi:10.1038/nature13642

12. Zheng S, Chen B, Qiu X, Chen M, Ma Z, Yu X. Distribution and risk assessment of 82 pesticides in Jiulong River and estuary. Chemosphere (2016) 144:1177-92. doi:10.1016/j.chemosphere.2015.09.050

13. Pirsaheb M, Limoee M, Namdari F, Khamutian R. Organochlorine pesticides residue in breast milk: a systematic review. Med J Islam Repub Iran (2015) 29:228.

14. Semchuk KM, Love EJ, Lee RG. Parkinson's disease and exposure to agricultural work and pesticide chemicals. Neurology (1992) 42:1328-35. doi:10.1212/WNL.42.7.1328

15. Wesseling C, McConnell R, Partanen T, Hogstedt C. Agricultural pesticide use in developing countries: health effects and research needs. Int $J$ Health Serv (1997) 27:273-308. doi:10.2190/E259-N3AH-TA1Y-H591

16. Eskenazi B, Bradman A, Castorina R. Exposures of children to organophosphate pesticides and their potential adverse health effects. Environ Health Perspect (1999) 107:409-19. doi:10.1289/ehp.99107s3409

17. Jaeger JW, Carlson IH, Porter WP. Endocrine, immune, and behavioral effects of aldicarb (carbamate), atrazine (triazine) and nitrate (fertilizer) mixtures at groundwater concentrations. Toxicol Ind Health (1999) 15:133-51. doi:10.1177/074823379901500111

18. García AM. Pesticide exposure and women's health. Am J Ind Med (2003) 44:584-94. doi:10.1002/ajim.10256

19. Salameh P, Waked M, Baldi I, Brochard P, Saleh BA. Respiratory diseases and pesticide exposure: a case-control study in Lebanon. J Epidemiol Community Health (2006) 60:256-61. doi:10.1136/jech.2005.039677

20. Weisenburger DD. Human health effects of agrichemical use. Hum Pathol (1993) 24:571-6. doi:10.1016/0046-8177(93)90234-8

21. Bradberry SM, Proudfoot AT, Vale JA. Glyphosate poisoning. Toxicol Rev (2004) 23:159-67. doi:10.2165/00139709-200423030-00003

22. Bretveld RW, Thomas CMG, Scheepers PTJ, Zielhuis GA, Roeleveld N. Pesticide exposure: the hormonal function of the female reproductive system disrupted? Reprod Biol Endocrinol (2006) 4:30. doi:10.1186/1477-7827-4-30

23. Bassil KL, Vakil C, Sanborn M, Cole DC, Kaur JS, Kerr KJ. Cancer health effects of pesticides. Systematic review. Can Fam Physician (2007) 53:1704-11.

24. Hoppin JA, Umbach DM, London SJ, Henneberger PK, Kullman GJ, Alavanja MCR, et al. Pesticides and atopic and nonatopic asthma among farm women in the agricultural health study. Am J Respir Crit Care Med (2008) 177:11-8. doi:10.1164/rccm.200706-821OC

25. Bjørling-Poulsen M, Andersen HR, Grandjean P. Potential developmental neurotoxicity of pesticides used in Europe. Environ Health (2008) 7:50. doi:10.1186/1476-069X-7-50

26. Roeleveld N, Bretveld R. The impact of pesticides on male fertility. Curr Opin Obstet Gynecol (2008) 20:229-33. doi:10.1097/GCO.0b013e3282fcc334

27. Osman KA. Pesticides and human health. In: Stoytcheva M, editor. Pesticides in the Modern World - Effects of Pesticides Exposure. InTech (2011). p. 206-30. Available from: http://www.intechopen.com/books/ pesticides-in-the-modern-world-effects-of-pesticides-exposure/ pesticides-and-human-health

28. Mostafalou S, Abdollahi M. Pesticides and human chronic diseases: evidences, mechanisms, and perspectives. Toxicol Appl Pharmacol (2013) 268:157-77. doi:10.1016/j.taap.2013.01.025

29. Séralini GE, Clair E, Mesnage R, Gress S, Defarge N, Malatesta M, et al. Republished study: long-term toxicity of a Roundup herbicide and a Roundup-tolerant genetically modified maize. Environ Sci Eur (2014) 26:14. doi:10.1186/s12302-014-0014-5

30. Thakur DS, Khot R, Joshi PP, Pandharipande M, Nagpure K. Glyphosate poisoning with acute pulmonary edema. Toxicol Int (2014) 21:328-30. doi:10.4103/0971-6580.155389

31. Gunnell D, Eddleston M, Phillips MR, Konradsen F. The global distribution of fatal pesticide self-poisoning: systematic review. BMC Public Health (2007) 7:357. doi:10.1186/1471-2458-7-357

32. McGill AE, Robinson J. Organochlorine insecticide residues in complete prepared meals: a 12-month survey in S.E. England. Food Cosmet Toxicol (1968) 6:45-57. doi:10.1016/0015-6264(68)90080-1

33. Cabras P, Angioni A. Pesticide residues in grapes, wine, and their processing products. J Agric Food Chem (2000) 48:967-73. doi:10.1021/jf990727a
34. Zambonin CG, Quinto M, De Vietro N, Palmisano F. Solid-phase microextraction - gas chromatography mass spectrometry: a fast and simple screening method for the assessment of organophosphorus pesticides residues in wine and fruit juices. Food Chem (2004) 86:269-74. doi:10.1016/j. foodchem.2003.09.025

35. Burnett M, Welford R. Case study: coca-cola and water in India: episode 2. Corp Soc Responsib Environ Mgmt (2007) 14:298-304. doi:10.1002/csr.97

36. Lorenzin M. Pesticide residues in Italian ready-meals and dietary intake estimation. JEnviron Sci Health B (2007) 42:823-33. doi:10.1080/03601230701555021

37. Nag SK, Raikwar MK. Persistent organochlorine pesticides residues in animal feed. Environ Monit Assess (2011) 174:327-35. doi:10.1007/ s10661-010-1460-1

38. Witczak A, Abdel-Gawad H. Assessment of health risk from organochlorine pesticides residues in high-fat spreadable foods produced in Poland. J Environ Sci Health B (2014) 49:917-28. doi:10.1080/03601234.2014.951574

39. Chourasiya S, Khillare PS, Jyethi DS. Health risk assessment of organochlorine pesticide exposure through dietary intake of vegetables grown in the periurban sites of Delhi, India. Environ Sci Pollut Res Int (2015) 22:5793-806. doi:10.1007/s11356-014-3791-x

40. Reiler E, Jørs E, Bælum J, Huici O, Alvarez Caero MM, Cedergreen N. The influence of tomato processing on residues of organochlorine and organophosphate insecticides and their associated dietary risk. Sci Total Environ (2015) 527-528:262-9. doi:10.1016/j.scitotenv.2015.04.081

41. Nougadére A, Sirot V, Kadar A, Fastier A, Truchot E, Vergnet C, et al. Total diet study on pesticide residues in France: levels in food as consumed and chronic dietary risk to consumers. Environ Int (2012) 45:135-50. doi:10.1016/j.envint.2012.02.001

42. Blaznik U, Yngve A, Eržen I, Hlastan Ribič C. Consumption of fruits and vegetables and probabilistic assessment of the cumulative acute exposure to organophosphorus and carbamate pesticides of schoolchildren in Slovenia. Public Health Nutr (2015) 19(3):557-63. doi:10.1017/S1368980015001494

43. Kortenkamp A. Ten years of mixing cocktails: a review of combination effects of endocrine-disrupting chemicals. Environ Health Perspect (2007) 115:98-105. doi:10.1289/ehp. 9357

44. Damgaard IN, Skakkebaek NE, Toppari J, Virtanen HE, Shen H, Schramm $\mathrm{KW}$, et al. Persistent pesticides in human breast milk and cryptorchidism. Environ Health Perspect (2006) 114:1133-8. doi:10.1289/ehp.8741

45. Buscail C, Chevrier C, Serrano T, Pelé F, Monfort C, Cordier S, et al. Prenatal pesticide exposure and otitis media during early childhood in the PELAGIE mother-child cohort. Occup Environ Med (2015) 72(12):837-44. doi:10.1136/ oemed-2015-103039

46. Lu D, Wang D, Ni R, Lin Y, Feng C, Xu Q, et al. Organochlorine pesticides and their metabolites in human breast milk from Shanghai, China. Environ Sci Pollut Res Int (2015) 22:9293-306. doi:10.1007/s11356-015-4072-z

47. Baylis AD. Why glyphosate is a global herbicide: strengths, weaknesses and prospects. Pest Manag Sci (2000) 56:299-308. doi:10.1002/ (SICI)1526-4998(200004)56:4<299:AID-PS144>3.0.CO;2-K

48. Turusov V, Rakitsky V, Tomatis L. Dichlorodiphenyltrichloroethane (DDT): ubiquity, persistence, and risks. Environ Health Perspect (2002) 110:125-8. doi:10.1289/ehp.02110125

49. Van den Berg H. Global status of DDT and its alternatives for use in vector control to prevent disease. Environ Health Perspect (2009) 117:1656-63. doi:10.1289/ehp.0900785

50. Rodríguez-Alcalá LM, Sá C, Pimentel LL, Pestana D, Teixeira D, Faria A, et al. Endocrine disruptor DDE associated with a high-fat diet enhances the impairment of liver fatty acid composition in rats. J Agric Food Chem (2015) 63:9341-8. doi:10.1021/acs.jafc.5b03274

51. Eskenazi B, Marks AR, Bradman A, Fenster L, Johnson C, Barr DB, et al. In utero exposure to dichlorodiphenyltrichloroethane (DDT) and dichlorodiphenyldichloroethylene (DDE) and neurodevelopment among young Mexican American children. Pediatrics (2006) 118:233-41. doi:10.1542/ peds.2005-3117

52. Lemaire G, Terouanne B, Mauvais P, Michel S, Rahman R. Effect of organochlorine pesticides on human androgen receptor activation in vitro. Toxicol Appl Pharmacol (2004) 196:235-46. doi:10.1016/j.taap.2003.12.011

53. Tiemann U. In vivo and in vitro effects of the organochlorine pesticides DDT, TCPM, methoxychlor, and lindane on the female reproductive tract 
of mammals: a review. Reprod Toxicol (2008) 25:316-26. doi:10.1016/j. reprotox.2008.03.002

54. Karami-Mohajeri S, Abdollahi M. Toxic influence of organophosphate, carbamate, and organochlorine pesticides on cellular metabolism of lipids, proteins, and carbohydrates: a systematic review. Hum Exp Toxicol (2011) 30(9):1119-40. doi:10.1177/0960327110388959

55. Freire C, Koifman RJ, Koifman S. Hematological and hepatic alterations in brazilian population heavily exposed to organochlorine pesticides. J Toxicol Environ Health A (2015) 78:534-48. doi:10.1080/15287394.2014.999396

56. Calle EE, Frumkin H, Henley SJ, Savitz DA, Thun MJ. Organochlorines and breast cancer risk. CA Cancer JClin (2002) 52:301-9. doi:10.3322/ canjclin.52.5.301

57. Robinson T, Ali U, Mahmood A, Chaudhry MJ, Li J, Zhang G, et al. Concentrations and patterns of organochlorines (OCs) in various fish species from the Indus River, Pakistan: a human health risk assessment. Sci Total Environ (2015) 541:1232-42. doi:10.1016/j.scitotenv.2015.10.002

58. Jaga K, Dharmani C. Sources of exposure to and public health implications of organophosphate pesticides. Rev Panam Salud Publica (2003) 14:171-85. doi:10.1590/S1020-49892003000800004

59. McKinlay R, Plant JA, Bell JNB, Voulvoulis N. Endocrine disrupting pesticides: implications for risk assessment. Environ Int (2008) 34:168-83. doi:10.1016/j.envint.2007.07.013

60. Gasnier C, Dumont C, Benachour N, Clair E, Chagnon MC, Séralini GE. Glyphosate-based herbicides are toxic and endocrine disruptors in human cell lines. Toxicology (2009) 262:184-91. doi:10.1016/j.tox.2009.06.006

61. Li D, Huang Q, Lu M, Zhang L, Yang Z, Zong M, et al. The organophosphate insecticide chlorpyrifos confers its genotoxic effects by inducing DNA damage and cell apoptosis. Chemosphere (2015) 135:387-93. doi:10.1016/j. chemosphere.2015.05.024

62. Hung DZ, Yang HJ, Li YF, Lin CL, Chang SY, Sung FV, et al. The long-term effects of organophosphates poisoning as a risk factor of CVDs: a nationwide population-based cohort study. PLoS One (2015) 10:e0137632. doi:10.1371/ journal.pone. 0137632

63. Jamal F, Haque QS, Singh S, Rastogi S. The influence of organophosphate and carbamate on sperm chromatin and reproductive hormones among pesticide sprayers. Toxicol Ind Health (2015):1-10. doi:10.1177/0748233714568175

64. Rosenstock L, Keifer M, Daniell WE, McConnell R, Claypoole K. Chronic central nervous system effects of acute organophosphate pesticide intoxication. Lancet (1991) 338:223-7. doi:10.1016/0140-6736(91)90356-T

65. Wesseling C, Keifer M, Ahlbom A, McConnell R, Moon J-D, Rosenstock L, et al. Long-term neurobehavioral effects of mild poisonings with organophosphate and n-methyl carbamate pesticides among banana workers. Int $J$ Occup Environ Health (2002) 8:27-34. doi:10.1179/oeh.2002.8.1.27

66. Eskenazi B, Harley K, Bradman A, Fenster L, Wolff M, Engel S, et al. In utero pesticide exposure and neurodevelopment in three NIEHS/environmental agency children's center birth cohorts. Epidemiology (2006) 17:S103. doi:10.1097/00001648-200611001-00249

67. Lin JN, Lin CL, Lin MC, Lai CH, Lin HH, Yang CH, et al. Increased risk of dementia in patients with acute organophosphate and carbamate poisioning: a nationwide population-based cohort study. Medicine (Baltimore) (2015) 94:e1187. doi:10.1097/MD.0000000000001187

68. Waddell BL, Zahm SH, Baris D, Weisenburger DD, Holmes F, Burmeister LF, et al. Agricultural use of organophosphate pesticides and the risk of non-Hodgkin's lymphoma among male farmers (United States). Cancer Causes Control (2001) 12:509-17. doi:10.1023/A:1011293208949

69. Eskenazi B, Harley K, Bradman A, Weltzien E, Jewel NP, Barr DB, et al. Association of in Utero organophosphate pesticide exposure and fetal growth and length of gestation in an agricultural population. Environ Health Perspect (2004) 112:1116-24. doi:10.1289/ehp.6789

70. Rauh VA, Garcia WE, Whyatt RM, Horton MK, Barr DB, Louis ED. Prenatal exposure to the organophosphate pesticide chlorpyrifos and childhood tremor. Neurotoxicology (2015) 51:80-6. doi:10.1016/j.neuro.2015.09.004

71. Williams GM, Kroes R, Munro IC. Safety evaluation and risk assessment of the herbicide Roundup and its active ingredient, glyphosate, for humans. Regul Toxicol Pharmacol (2000) 31:117-65. doi:10.1006/rtph.1999.1371

72. Mink PJ, Mandel JS, Lundin JI, Sceurman BK. Epidemiologic studies of glyphosate and non-cancer health outcomes. Regul Toxicol Pharmacol (2011) 61:172-84. doi:10.1016/j.yrtph.2011.07.006
73. Mink PJ, Mandel JS, Sceurman BK, Lundin JI. Epidemiologic studies of glyphosate and cancer: a review. Regul Toxicol Pharmacol (2012) 63:440-52. doi:10.1016/j.yrtph.2012.05.012

74. Cuhra M, Traavik T, Bøhn T. Clone- and age-dependent toxicity of a glyphosate commercial formulation and its active ingredient in Daphnia magna. Ecotoxicology (2013) 22:251-62. doi:10.1007/s10646-012-1021-1

75. Campbell AW. Glyphosate: its effects on humans. Altern Ther Health Med (2014) 20:9-11.

76. Samsel A, Seneff S. Glyphosate's suppression of cytochrome P450 enzymes and amino acid biosynthesis by the gut microbiome: pathways to modern diseases. Entropy (2013) 15:1416-63. doi:10.3390/e15041416

77. Woodburn AT. Glyphosate: production, pricing and use worldwide. Pest Manag Sci (2000) 56:309-12. doi:10.1002/(SICI)1526-4998(200004)

78. Bonny S. Genetically modified glyphosate-tolerant soybean in the USA: adoption factors, impacts and prospects. A review. Agron Sustain Dev (2008) 28:21-32. doi:10.1051/agro:2007044

79. Duke SO, Powles SB. Glyphosate-resistant crops and weeds: now and in the future. AgBioForum (2009) 12:346-57.

80. Thongprakaisang S, Thiantanawat A, Rangkadilok N, Suriyo T, Satayavivad J. Glyphosate induces human breast cancer cells growth via estrogen receptors. Food Chem Toxicol (2013) 59:129-36. doi:10.1016/j. fct.2013.05.057

81. Fukutake M, Takahashi M, Ishida K, Kawamura H, Sugimura T, Wakabayashi K. Quantification of genistein and genistin in soybeans and soybean products. Food Chem Toxicol (1996) 34:457-61. doi:10.1016/0278-6915(96)87355-8

82. Swanson NL, Leu A, Abrahamson J, Wallet B. Genetically engineered crops, glyphosate and the deterioration of health in the United States of America. J Org Syst (2014) 9:6-37.

83. Kwiatkowska M, Huras B, Bukowska B. The effect of metabolites and impurities of glyphosate on human erythrocytes (in vitro). Pestic Biochem Physiol (2014) 109:34-43. doi:10.1016/j.pestbp.2014.01.003

84. George J, Prasad S, Mahmood Z, Shukla Y. Studies on glyphosate-induced carcinogenicity in mouse skin: a proteomic approach. JProteomics (2010) 73:951-64. doi:10.1016/j.jprot.2009.12.008

85. Samsel A, Seneff S. Glyphosate, pathways to modern diseases III: manganese, neurological diseases, and associated pathologies. Surg Neurol Int (2015) 6:45. doi:10.4103/2152-7806.153876

86. Pieniażek D, Bukowska B, Duda W. Comparison of the effect of Roundup Ultra 360 SL pesticide and its active compound glyphosate on human erythrocytes. Pestic Biochem Physiol (2004) 79:58-63. doi:10.1016/j.pestbp.2004.03.003

87. Kwiatkowska M, Pawel J, Bukowska B. Glyphosate and its formulations - toxicity, occupational and environmental exposure (Article in Polish). Med $\mathrm{Pr}$ (2013) 64:717-29. doi:10.13075/mp.5893.2013.0059

88. Clair É, Mesnage R, Travert C, Séralini G-É. A glyphosate-based herbicide induces necrosis and apoptosis in mature rat testicular cells in vitro, and testosterone decrease at lower levels. Toxicol In Vitro (2012) 26:269-79. doi:10.1016/j.tiv.2011.12.009

89. Gehin A, Guyon C, Nicod L. Glyphosate-induced antioxidant imbalance in HaCaT: the protective effect of Vitamins $\mathrm{C}$ and E. Environ Toxicol Pharmacol (2006) 22:27-34. doi:10.1016/j.etap.2005.11.003

90. de Liz Oliveira Cavalli VL, Cattani D, Heinz Rieg CE, Pierozan P, Zanatta L, Benedetti Parisotto E, et al. Roundup disrupts male reproductive functions by triggering calcium-mediated cell death in rat testis and Sertoli cells. Free Radic Biol Med (2013) 65:335-46. doi:10.1016/j.freeradbiomed.2013.06.043

91. Hedberg D, Wallin M. Effects of Roundup and glyphosate formulations on intracellular transport, microtubules and actin filaments in Xenopus laevis melanophores. Toxicol In Vitro (2010) 24:795-802. doi:10.1016/j. tiv.2009.12.020

92. Samsel A, Seneff S. Glyphosate, pathways to modern diseases II: celiac sprue and gluten intolerance. Interdiscip Toxicol (2013) 6:159-84. doi:10.2478/ intox-2013-0026

93. Goad ER, Goad JT, Atieh BH, Gupta RC. Carbofuran-induced endocrine disruption in adult male rats. Toxicol Mech Methods (2004) 14:233-9. doi:10.1080/15376520490434476

94. Soloneski S, Kujawski M, Scuto A, Larramendy ML. Carbamates: a study on genotoxic, cytotoxic, and apoptotic effects induced in Chinese hamster ovary (CHO-K1) cells. Toxicol In Vitro (2015) 29:834-44. doi:10.1016/j. tiv.2015.03.011 
95. Li Q, Kobayashi M, Kawada T. Ziram induces apoptosis and necrosis in human immune cells. Arch Toxicol (2011) 85:355-61. doi:10.1007/ s00204-010-0586-9

96. Li Q, Kobayashi M, Kawada T. Mechanism of ziram-induced apoptosis in human natural killer cells. Int J Immunopathol Pharmacol (2012) 25:883-91. doi:10.1177/039463201202500406

97. Li Q, Kobayashi M, Kawada T. Carbamate pesticide-induced apoptosis and necrosis in human natural killer cells. J Biol Regul Homeost Agents (2014) 28:23-32.

98. Li Q, Kobayashi M, Kawada T. Carbamate pesticide-induced apoptosis in human T lymphocytes. Int J Environ Res Public Health (2015) 12:3633-45. doi:10.3390/ijerph120403633

99. Denison MS, Phelan D, Winter GM, Ziccardi MH. Carbaryl, a carbamate insecticide, is a ligand for the hepatic ah (dioxin) receptor. Toxicol Appl Pharmacol (1998) 152:406-14. doi:10.1006/taap.1998.9999

100. Lifshitz M, Shahak E, Bolotin A, Sofer S. Carbamate poisoning in early childhood and in adults. J Toxicol Clin Toxicol (1997) 35:25-7. doi:10.3109/15563659709001161

101. ZhengT,ZahmSH,CantorKP,WeisenburgerDD,ZhangY,Blair A.Agricultural exposure to carbamate pesticides and risk of non-hodgkin lymphoma.J Occup Environ Med (2001) 43:641-9. doi:10.1097/00043764-200107000-00012

102. Kniewald J, Jakominić M, Tomljenović A, Simić B, Romać P, Vranesić D, et al. Disorders of male rat reproductive tract under the influence of atrazine. J Appl Toxicol (2000) 20:61-8. doi:10.1002/ (SICI)1099-1263(200001/02)20:1<61:AID-JAT628>3.0.CO;2-3

103. Jin Y, Wang L, Chen G, Lin X, Miao W, Fu Z. Exposure of mice to atrazine and its metabolite diaminochlorotriazine elicits oxidative stress and endocrine disruption. Environ Toxicol Pharmacol (2014) 37:782-90. doi:10.1016/j. etap.2014.02.014

104. Kettles MK, Browning SR, Prince TS, Horstman SW. Triazine herbicide exposure and breast cancer incidence: an ecologic study of Kentucky counties. Environ Health Perspect (1997) 105:1222-7. doi:10.1289/ehp.971051222

105. Liu XM, Shao JZ, Xiang LX, Chen XY. Cytotoxic effects and apoptosis induction of atrazine in a grass carp (Ctenopharyngodon idellus) cell line. Environ Toxicol (2006) 21:80-9. doi:10.1002/tox.20159

106. Huang P, Yang J, Song Q. Atrazine affects phosphoprotein and protein expression in MCF-10A human breast epithelial cells. Int J Mol Sci (2014) 15:17806-26. doi:10.3390/ijms151017806

107. Li YS, He X, Ma K, Wu YP, Li BX. The effect of exposure to atrazine on dopaminergic development in pubertal male SD rats. Birth Defects Res B Dev Reprod Toxicol (2015) 104:184-9. doi:10.1002/bdrb.21151

108. Ma K, Wu HY, Zhang B, He X, Li BX. Neurotoxicity effects of atrazine-induced SH-SY5Y human dopaminergic neuroblastoma cells via microglial activation. Mol Biosyst (2015) 11:2915-24. doi:10.1039/c5mb00432b

109. Song Y, Jia ZC, Chen JY, Hu JX, Zhang LS. Toxic effects of atrazine on reproductive system of male rats. Biomed Environ Sci (2014) 27:281-8. doi: $10.3967 /$ bes 2014.050

110. Breckenridge CB, Sawhney Coder P, Tisdel MO, Simpkins JW, Yi KD, Foradori $\mathrm{CD}$, et al. Effect of age, duration of exposure, and dose of atrazine on sexual maturation and the luteinizing hormone surge in the female Sprague-Dawley rat. Birth Defects Res B Dev Reprod Toxicol (2015) 104:204-17. doi:10.1002/ bdrb. 21154

111. Kolaczinski JH, Curtis CF. Chronic illness as a result of low-level exposure to synthetic pyrethroid insecticides: a review of the debate. Food Chem Toxicol (2004) 42:697-706. doi:10.1016/j.fct.2003.12.008

112. Ray DE, Fry JR. A reassessment of the neurotoxicity of pyrethroid insecticides. Pharmacol Ther (2006) 111:174-93. doi:10.1016/j.pharmthera.2005.10.003

113. Garey J, Wolff MS. Estrogenic and antiprogestagenic activities of pyrethroid insecticides. Biochem Biophys Res Commun (1998) 251:855-9. doi:10.1006/ bbrc. 1998.9569

114. Jaensson A, Scott AP, Moore A, Kylin H, Håkan Olsén K. Effects of a pyrethroid pesticide on endocrine responses to female odours and reproductive behaviour in male parr of brown trout (Salmo trutta L.). Aquat Toxicol (2007) 81:1-9. doi:10.1016/j.aquatox.2006.10.011

115. Pandey SP, Mohanty B. The neonicotinoid pesticide imidacloprid and the dithiocarbamate fungicide mancozeb disrupt the pituitary-thyroid axis of a wildlife bird. Chemosphere (2014) 122:227-34. doi:10.1016/j. chemosphere.2014.11.061

116. Moore A, Waring CP. The effects of a synthetic pyrethroid pesticide on some aspects of reproduction in Atlantic salmon (Salmo salar L.). Aquat Toxicol (2001) 52:1-12. doi:10.1016/S0166-445X(00)00133-8

117. Jurewicz J, Radwan M, Wielgomas B, Sobala W, Piskunowicz M, Radwan P, et al. The effect of environmental exposure to pyrethroids and DNA damage in human sperm. Syst Biol Reprod Med (2015) 61:37-43. doi:10.3109/ 19396368.2014.981886

118. Shafer TJ, Meyer DA, Crofton KM. Developmental neurotoxicity of pyrethroid insecticides: critical review and future research needs. Environ Health Perspect (2005) 113:123-36. doi:10.1289/ehp.7254

119. Syed F, John PJ, Soni I. Neurodevelopmental consequences of gestational and lactational exposure to pyrethroids in rats. Environ Toxicol (2015). doi:10.1002/tox. 22178

120. Goulson D. An overview of the environmental risks posed by neonicotinoid insecticides. J Appl Ecol (2013) 50:977-87. doi:10.1111/1365-2664.12111

121. Jeschke P, Nauen R. Neonicotinoids - from zero to hero in insecticide chemistry. Pest Manag Sci (2008) 64:1084-98. doi:10.1002/ps.1631

122. Qi S, Wang C, Chen X, Qin Z, Li X, Wang C. Toxicity assessments with Daphnia magna of Guadipyr, a new neonicotinoid insecticide and studies of its effect on acetylcholinesterase (AChE), glutathione S-transferase (GST), catalase (CAT) and chitobiase activities. Ecotoxicol Environ Saf (2013) 98:339-44. doi:10.1016/j.ecoenv.2013.09.013

123. Put K, Bollens T, Wäckers F, Pekas A. Non-target effects of commonly used plant protection products in roses on the predatory mite Euseius gallicus Kreiter \& Tixier (Acari: Phytoseidae). Pest Manag Sci (2016) 72(7):1373-80. doi:10.1002/ps.4162

124. Williams GR, Troxler A, Retschnig G, Roth K, Yañez O, Shutler D, et al. Neonicotinoid pesticides severely affect honey bee queens. Sci Rep (2015) 5:14621. doi: $10.1038 /$ srep 14621

125. Wright GA, Softley S, Earnshaw H. Low doses of neonicotinoid pesticides in food rewards impair short-term olfactory memory in foraging-age honeybees. Sci Rep (2015) 5:15322. doi:10.1038/srep15322

126. Bal R, Naziroğlu M, Türk G, Yilmaz Ö, Kuloğlu T, Etem E, et al. Insecticide imidacloprid induces morphological and DNA damage through oxidative toxicity on the reproductive organs of developing male rats. Cell Biochem Funct (2012) 30:492-9. doi:10.1002/cbf.2826

127. Hoshi N, Hirano T, Omotehara T, Tokumoto J, Umemura Y, Mantani Y. Insight into the mechanism of reproductive dysfunction caused by neonicotinoid pesticides. Biol Pharm Bull (2014) 37:1439-43. doi:10.1248/bpb b14-00359

128. Caron-Beaudoin É, Denison MS, Sanderson JT. Effects of neonicotinoids on promoter-specific expression and activity of aromatase (CYP19) in human adrenocortical carcinoma (H295R) and primary umbilical vein endothelial (HUVEC) cells. Toxicol Sci (2016) 149(1):134-44. doi:10.1093/toxsci/kfv220

129. Pierce FJ, Nowak P. Aspects of precision agriculture. Adv Agron (1999) 67:1-85. doi:10.1016/S0065-2113(08)60513-1

130. Robert PC. Precision agriculture: a challenge for crop nutrition management. Plant Soil (2002) 247:143-9. doi:10.1023/A:1021171514148

131. Zhang N, Wang M, Wang N. Precision agriculture - a worldwide overview. Compu Electron Agr (2002) 36:113-32. doi:10.1016/S0168-1699(02)00096-0

132. Bongiovanni R, Lowenberg-DeBoer J. Precision agriculture and sustainability. Precision Agric (2004) 5:359-87. doi:10.1023/B:PRAG.0000040806.39604. aa

133. McBratney A, Whelan B, Ancev T, Bouma J. Future direction of precision agriculture. Precision Agric (2005) 6:7-23. doi:10.1007/s11119-005-0681-8

134. Watcharaanantapong P, Roberts RK, Lambert DM, Larson JA, Velandia M, English BC, et al. Timing of precision agriculture technology adoption in US cotton production. Precision Agric (2014) 15:427-46. doi:10.1007/ s11119-013-9338-1

135. Zhang C, Kovacs JM. The application of small unmanned aerial systems for precision agriculture: a review. Precision Agric (2012) 13:693-712. doi:10.1007/s11119-012-9274-5

136. Hertoge K. Mals/Malles Venosta Referendum. (2014). Available from: http:// www.marcozullo.it/wp-content/uploads/Malles-Venosta-Referendum.pdf 
137. Menezes F. Food sovereignty: a vital requirement for food security in the context of globalization. Development (2001) 44:29-33. doi:10.1057/palgrave. development.1110288

138. Windfuhr M, Jonsén J. Food Sovereignty. Towards Democracy in Localized Food Systems. Chippenham, GB: ITDG Publishing (2005).

139. Declaration of Nyéléni. (2007). Available from: http://nyeleni.org/spip. php?article290

140. Patel R. Food sovereignty. J Peasant Stud (2009) 36:663-706. doi:10.1080/03066150903143079

141. Wittman H. Food sovereignty: a new rights framework for food and nature? Environ Soc Adv Res (2011) 2:87-105. doi:10.3167/ares.2011.020106

142. Pimbert M. Towards Food Sovereignty: Reclaiming Autonomous Food Systems. London, Munich: CAFS, IIED, RCC (2009). Available from: http://pubs.iied. org/pdfs/G02268.pdf

143. Altieri MA. Agroecology, small farms, and food sovereignty. Mon Rev (2009) 61:102-13. doi:10.14452/MR-061-03-2009-07_8

144. Holt-Giménez E. From food crisis to food sovereignty. The challenge of social movements. Mon Rev (2009) 61:142-56. doi:10.14452/ MR-061-03-2009-07_11

145. Rosset P. Food sovereignty and the contemporary food crisis. Development (2008) 51:460-3. doi:10.1057/dev.2008.48

146. Panagiotakopulu E, Buckland PC, Day PM, Sarpaki AA, Doumas C. Natural insecticides and insect repellents in antiquity: a review of the evidence. J Archaeol Sci (1995) 22:705-10. doi:10.1016/S0305-4403(95)80156-1

147. Fry DM. Reproductive effects in birds exposed to pesticides and industrial chemicals. Environ Health Perspect (1995) 103:165-71. doi:10.2307/3432528

148. Shukla G, Kumar A, Bhanti M, Joseph PE, Taneja A. Organochlorine pesticide contamination of ground water in the city of Hyderabad. Environ Int (2006) 32:244-7. doi:10.1016/j.envint.2005.08.027

149. Hemingway J, Ranson H. Insecticide resistance in insect vectors of human disease. Annu Rev Entomol (2000) 45:371-91. doi:10.1146/annurev. ento.45.1.371

150. Olesen JE, Bindi M. Consequences of climate change for European agricultural productivity, land use and policy. Eur J Agron (2002) 16:239-62. doi:10.1016/S1161-0301(02)00004-7

151. Taiz L. Agriculture, plant physiology, and human population growth: past, present, and future. Theor Exp Plant Physiol (2013) 25:167-81. doi:10.1590/ S2197-00252013000300001

152. Steenwerth KL, Hodson AK, Bloom AJ, Carter MR, Cattaneo A, Chartres CJ, et al. Climate-smart agriculture global research agenda: scientific basis for action. Agr Food Secur (2014) 3:11. doi:10.1186/2048-7010-3-11

153. Tissier J, Grosclaude JY. What about climate-smart agriculture? In: Torquebiau E, editor. Climate Change and Agriculture Worldwide. Dordrecht, Heidelberg, New York, London: Springer Science + Business Media Dordrecht (2016). p. $313-24$.

154. McIntyre BD, Herren HR, Wakhungu J, Watson RT, editors. Agriculture at a Crossroads. IAASTD Global Report. Washington, Covelo, London: Island Press, IAASTD (2009). Available from: http://www.unep.org/dewa/
agassessment/reports/IAASTD/EN/Agriculture\%20at\%20a\%20Crossroads_ Global\%20Report\%20(English).pdf

155. UNCTAD, UNEP. Organic Agriculture and Food Security in Africa. New York, Geneva: United Nations (2008). Available from: http://unctad.org/en/docs/ ditcted200715_en.pdf

156. Dona A, Arvanitoyannis IS. Health risks of genetically modified foods. Crit Rev Food Sci Nutr (2009) 49:164-75. doi:10.1080/10408390701855993

157. McHughen A. GM crops and foods. What do consumers want to know? GM Crops Food (2013) 4:172-82. doi:10.4161/gmcr.26532

158. Benbrook C. Do GM crops mean less pesticide use? Pestic Outlook (2001) 12:204-7. doi:10.1039/b108609j

159. Huang G, Hu R, Pray C, Qiao F, Rozelle S. Biotechnology as an alternative to chemical pesticides: a case study of Bt cotton in China. Agr Econ (2003) 29:55-67. doi:10.1016/S0169-5150(03)00044-6

160. Benbrook CM. Impacts of genetically engineered crops on pesticide use in the U.S. - the first sixteen years. Environ Sci Eur (2012) 24:24. doi:10.1186/2190-4715-24-24

161. Sexton K. Cumulative risk assessment: an overview of methodological approaches for evaluating combined health effects from exposure to multiple environmental stressors. Int J Environ Res Public Health (2012) 9:370-90. doi:10.3390/ijerph9020370

162. Colosio C, Alegakis AK, Tsatsakis AM. Emerging health issues from chronic pesticide exposure: innovative methodologies and effects on molecular cell and tissue level. Toxicology (2013) 307:1-2. doi:10.1016/j.tox.2013.04.006

163. Hernández AF, Parrón T, Tsatsakis AM, Requena M, Alarcón R, LópezGuarnido O. Toxic effects of pesticide mixtures at a molecular level: their relevance to human health. Toxicology (2013) 307:136-45. doi:10.1016/j. tox.2012.06.009

164. Pimentel D, Burgess M. Environmental and economic benefits of reducing pesticide use. In: Pimentel D, Peshin R, editors. Integrated Pest Management. New York, Heidelberg, Dordrecht, London: Springer Science + Business Media Dordrecht (2014). p. 127-39.

165. European Commission. The Common Agricultural Policy: A partnership between Europe and Farmers. Luxembourg: Publications Office of the European Union (2012). Available from: http://ec.europa.eu/agriculture/ cap-overview/2012_en.pdf

Conflict of Interest Statement: The authors declare that the research was conducted in the absence of any commercial or financial relationships that could be construed as a potential conflict of interest.

Copyright (c) 2016 Nicolopoulou-Stamati, Maipas, Kotampasi, Stamatis and Hens. This is an open-access article distributed under the terms of the Creative Commons Attribution License (CC BY). The use, distribution or reproduction in other forums is permitted, provided the original author(s) or licensor are credited and that the original publication in this journal is cited, in accordance with accepted academic practice. No use, distribution or reproduction is permitted which does not comply with these terms. 